\title{
Soil Fertility Status of Available Calcium and Magnesium in Soil through Soil Fertility Mapping using GPS and GIS Techniques of Dharmaur Micro-Watershed Jagdalpur Block, Bastar District of (C.G.) State, India
}

\author{
S. Shailja Iyer*, G. P. Ayam and D. S. Thakur \\ Department of Soil Science and Agricultural Chemistry \\ College of Agriculture, IGKV, Raipur 492012, Chhattisgarh, India \\ *Corresponding author
}

\section{A B S T R A C T}

\begin{tabular}{|l|}
\hline Ke y w o r d s \\
Soil fertility \\
mapping, \\
GPS, GIS \\
\hline Article Info \\
\hline $\begin{array}{l}\text { Accepted: } \\
\text { 14 May } 2020 \\
\text { Available Online: } \\
\text { 10 June } 2020\end{array}$ \\
\hline
\end{tabular}

\section{Introduction}

Soil fertility be defined while the capability of soil in the direction of contribute nutrients to the plants in an sufficient amount, suitable quantity, and free from toxic elements. Thus a fertile soil may or may not be abundant depending leading crops, marketing condition in addition to several further factors (i.e., excessive acidity or alkalinity, the presence of toxic substance, deprived physical properties or an excess or deficit of water. However, every productive soil have to be fertile.

Nowadays GIS and GPS techniques are extensively used for assemble soil fertility maps which is a computer-based software system which stores, analysis, and displays spatial data variability in maps and become a powerful tool and mechanism of precision 
farming. In soil, calcium replaces hydrogen $(\mathrm{H})$ ions from the surface of soil particles when limestone is added to reduce soil acidity. It is essential for microorganisms as they turn crop residues into organic matter, release nutrients, and improve soil aggregation and water holding capacity.

Calcium helps enable nitrogen-fixing bacteria that form nodules on the roots of leguminous plants to capture atmospheric nitrogen gas and convert it into a form that plants can use. Magnesium also acts as a phosphorus carrier in plants. It is necessary for cell division and protein formation. Phosphorus uptake could not occur without magnesium, and vice versa. So, magnesium is essential for phosphate metabolism, plant respiration and the activation of several enzyme systems.(ISSS, 2015).

\section{Materials and Methods}

\section{Study area}

Chhattisgarh state is divided into 3 Agroclimatic zones - Chattisgarh plains, Bastar Plateau, and Northern Hill zone, each covering $51 \%, 28 \%$, and $21 \%$ of the total geographical area respectively. Bastar district comes under the Bastar Plateau zone.

The study area is the Dharmaur MicroWatershed in Jagdalpur block, Bastar District of Chhattisgarh state, which is located between $19^{\circ} 2^{\prime} 30^{\prime \prime}$ to $19^{\circ} 07^{\prime} 30^{\prime \prime} \mathrm{N}$ latitude and $81^{\circ} 55^{\prime}$ to $81^{\circ} 57^{\prime} 30^{\prime \prime} \mathrm{E}$ longitude with an altitude of ranging from 540-562 $\mathrm{m}$ above MSL.

The study area covers the majority of the part of Dharmaur, Kumhrawand and Tekameta villages and is surrounded by Kumhrawand village to the East, Tekameta village to the West, Indravati River to the North, and Bhadisgaon \& Biringpal villages to the South.

\section{District profile}

Bastar district is situated in the southern part of Chhattisgarh state, at the height of 550 meters above mean sea level. Bastar is surrounded by Kanker to the north, Dantewada to the west, Nowrangpur to the East and Sukma to the South. The area covered by forest in Bastar is $7112 \mathrm{sq} \mathrm{km}$, which is more than $75 \%$ of the total area of the district.

\section{Agro-ecological region}

The study area falls under Garjat Hills, Dandakaranya and the Eastern Ghats, hot moist sub-humid ESR, with deep loamy red and lateritic soils, low to medium AWC and LGP 180-210 days with average annual rainfall $1295 \mathrm{~mm}$ out of which $70 \%$ rainfall occurs during June-September.

\section{Climate and weather conditions}

The region comes under sub-humid climate. The average annual rainfall observed in the area is $1544 \mathrm{~mm}$. A significant amount of precipitation occurs between June to September (about 3-4 months), which is the main rice growing seasons. Rice is the major crop of the study area; other important crops are minor millets, maize, Niger, horse gram, black gram, green gram, and vegetables. Farmers adopt traditional methods of cultivation with a little use of chemical fertilizers and plant protection measures. Irrigation facilities are negligible (about 8\% of the cultivated area) hence; mono-cropping "rice-fallow" is prevalent.

\section{Soils of bastar}

The soil seen in the Bastar district is mainly laterite soil. Soils of red and yellow shades could also be found in patches in a few places of the district. The trap rocks occur over the 
slopes in the Abujhmar tract, where thin light shaded soil is seen. The beds of streams and rivers like Indravati, Godavari, and Mahanadi have fresh alluvial soil. The texture of the soil ranges from sandy to fine textured (clayed soil).

The $\mathrm{pH}$ of the soil varies from 4.5 to 6.5 (slightly acidic) in Sal forest areas and 5.5 to 7.8 (slightly basic) in teak forest areas, while other forests generally tend to have intermediate values. Despite the frequent summer fires, the percentage of the organic matter in the top layer of the soil is generally quite high, varying from 0.5 to $2.5 \%$.

\section{Estimation of available calcium and magnesium in soil}

Calcium and Magnesium status in soils was estimated by Versenate titration method using ammonium acetate extract and by titration with EDTA Versenate(Schwarzenbech,1946).

\section{Procedure}

Weight $10 \mathrm{~g}$ of soil sample in $150 \mathrm{~mL}$ conical flask, then add $50 \mathrm{~mL}$ of $1 \mathrm{~N}$ ammonium acetate solution and shake for 5 minutes, Filter through Whatman no. 1 filter paper. Pipette out $5 \mathrm{~mL}$ of soil extract in a porcelain dish. Add about $25 \mathrm{~mL}$ distilled water to it.

Add $5 \mathrm{~mL}$ of $\mathrm{NaOH}$ solution and then $50 \mathrm{~g}$ of murexide indicator, stirred well and the solution is titrated with standard $0.01 \mathrm{~N}$ EDTA till the color change from red to purple. The volume of EDTA used is noted.

\section{Ca + Mg determination}

Same as Ca determination pipette out $5 \mathrm{~mL}$ of soil extract in a porcelain dish. Add about 25 $\mathrm{mL}$ distilled water to it. Add $1 \mathrm{~mL}$ of NH CI$\mathrm{NH}, \mathrm{OH}$ buffer solution and then 3-5 drop of
EBT indicator, stirred well and the solution is titrated with standard 0.01 N EDTA till the color change from wine red to blue or green. The volume of EDTA used is noted.

\section{Mg determination}

The $\mathrm{Mg}$ content of the soil is determined from the difference between the contents of $\mathrm{Ca}+$ $\mathrm{Mg}$ and $\mathrm{Ca}$.

\section{Results and Discussion}

\section{Available calcium and magnesium}

The available Dharmaur micro-watershed calcium ranged from 32-146 ppm with a mean value of $79.1 \mathrm{ppm}$. The entire research region was stated under the low Ca status accessible. Similar to the results reported by Ganorkar along with Chinchmalatpure (2013) researched the nutrient status of Amravati District (Maharashtra) India soils. Soil parameters, such as soil $\mathrm{pH}$ and calcium content were evaluated. Results showed that calcium content ranged from 0.07 to 0.16 percent, and $\mathrm{pH}$ ranged from 7.80 to 8.46.

The nutrient index value of the accessible calcium in the study region soil falls under the low category. Status of accessible calcium in the research region soils shown on the soil fertility map in Fig.2. The accessible Dharmaur micro-watershed magnesium ranged from 66 to $449.6 \mathrm{ppm}$ with a mean value of $269 \mathrm{ppm}$. Of the 382 samples, 77.4 percent of the samples fell under elevated status, and 22.5 percent of the samples were low in Mg status.

The nutrient index value of accessible magnesium in the study region soil falls under the elevated category. Status of accessible $\mathrm{Mg}$ in soils from the research region shown in soil fertility map in Fig-3. 
Table.1 Distribution of available $\mathrm{Ca} \& \mathrm{Mg}$ status in the soils

\begin{tabular}{|l|c|c|c|c|}
\hline $\begin{array}{l}\text { Available Ca and } \\
\text { Mg (ppm) }\end{array}$ & $\begin{array}{c}\text { No. of } \\
\text { Samples }\end{array}$ & \% Samples & $\begin{array}{c}\text { Nutrient } \\
\text { Index }\end{array}$ & $\begin{array}{c}\text { Fertility } \\
\text { Rating }\end{array}$ \\
\hline Low (<448) & 382 & 100 & 1.00 & Low \\
\hline High (>448) & & & & \\
\cline { 1 - 3 } Available Mg & 382 & & 2.54 & High \\
\cline { 1 - 3 }$(<\mathbf{1 8 0})$ & & 22.5 & & \\
\hline High (>180) & & 77.4 & & \\
\hline
\end{tabular}

Table.2 Descriptive statistics of available $\mathrm{Ca}$ and $\mathrm{Mg}(0-15 \mathrm{~cm})$ depth of 382 soil Samples

\begin{tabular}{|l|c|c|}
\hline Descriptive Statistics & Ca(ppm) & Mg(ppm) \\
\hline Minimum & 32 & 66 \\
\hline Maximum & 146 & 449.4 \\
\hline 1st Quartile & 52 & 187.2 \\
\hline Median & 74.5 & 268.4 \\
\hline 3rd Quartile & 106 & 350 \\
\hline Mean & 79.13 & 269 \\
\hline Standard deviation & 31.18 & 97.34 \\
\hline Skewness & 0.34 & 0 \\
\hline
\end{tabular}

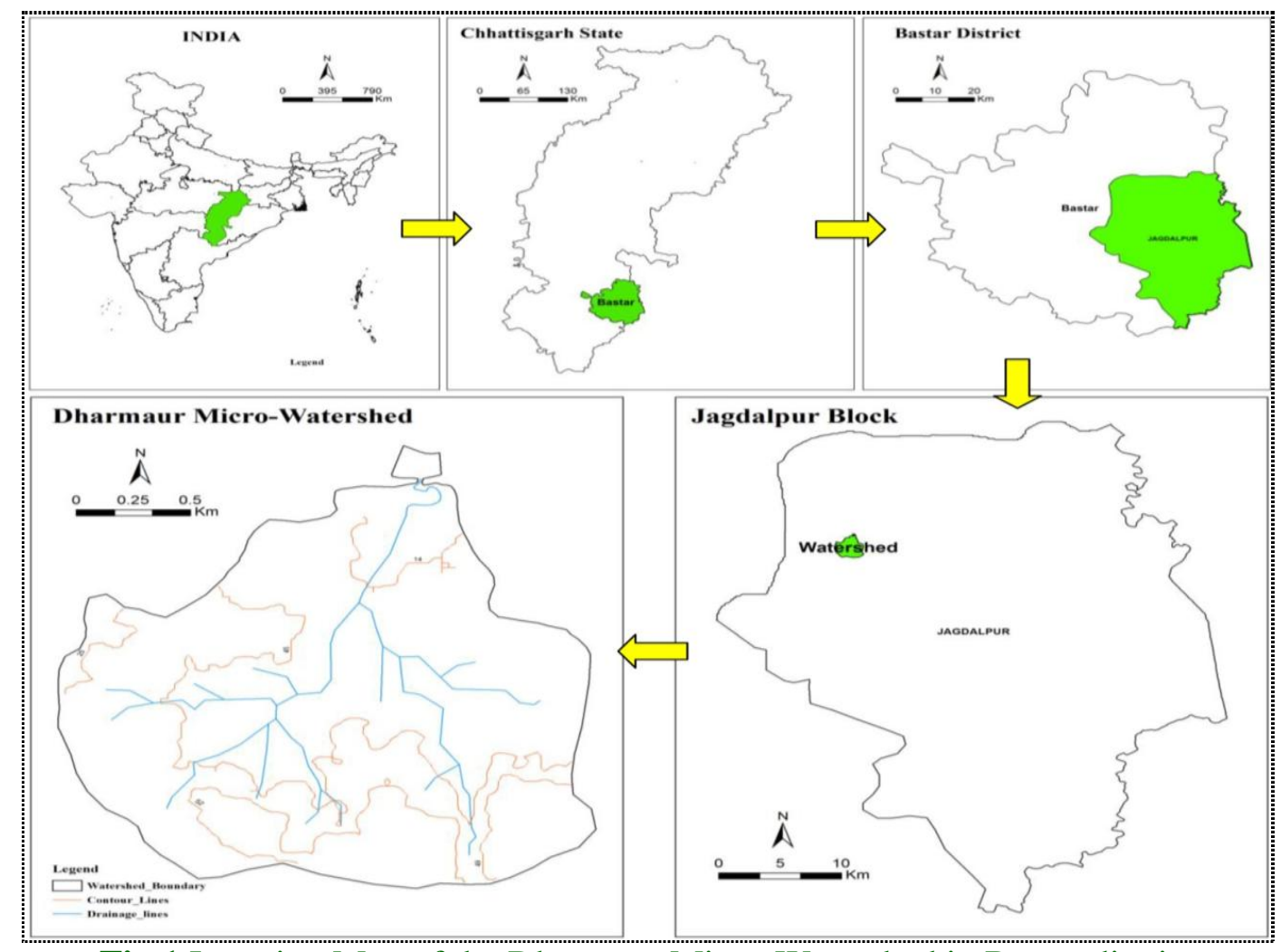

Fig.1 Location Map of the Dharmaur Micro-Watershed in Bastar district 


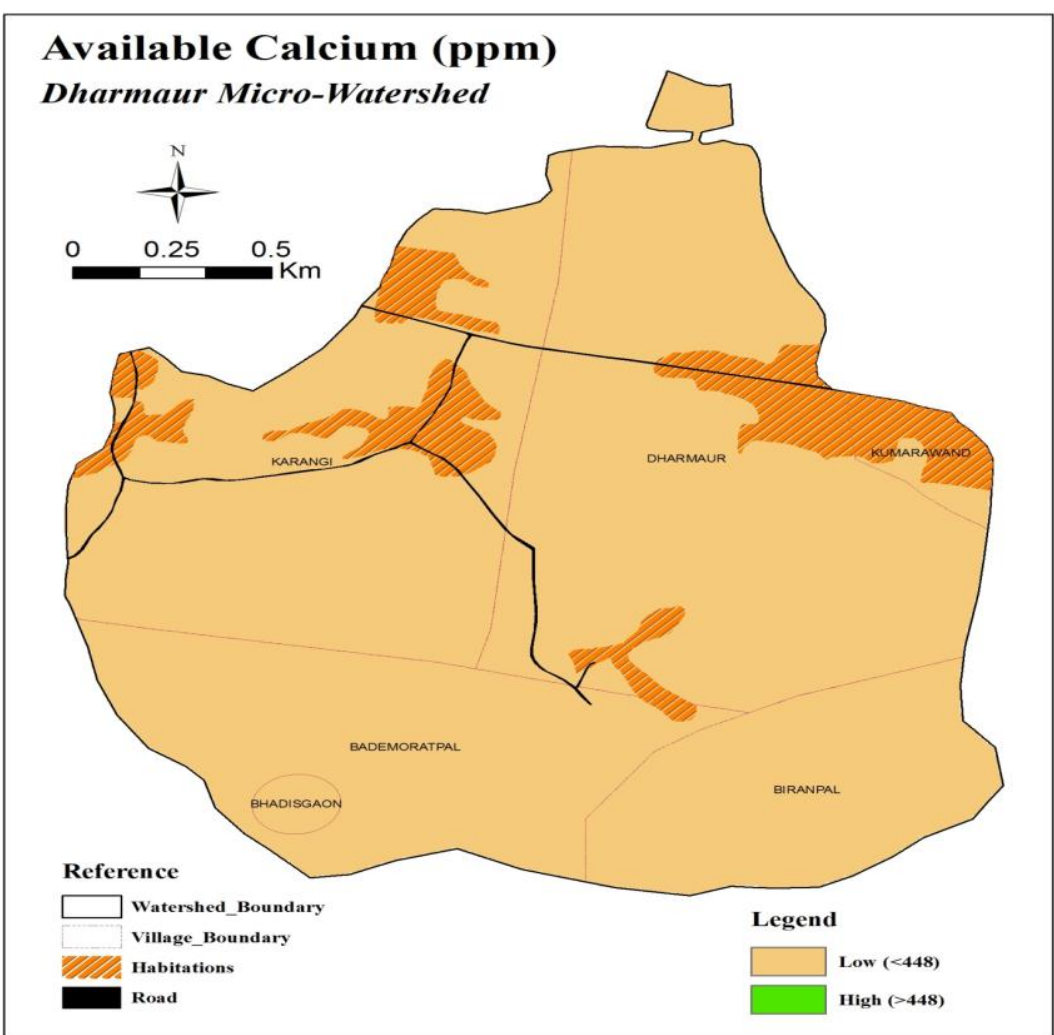

Fig.2 Status of available Ca soils of Dharmaur micro-watershed

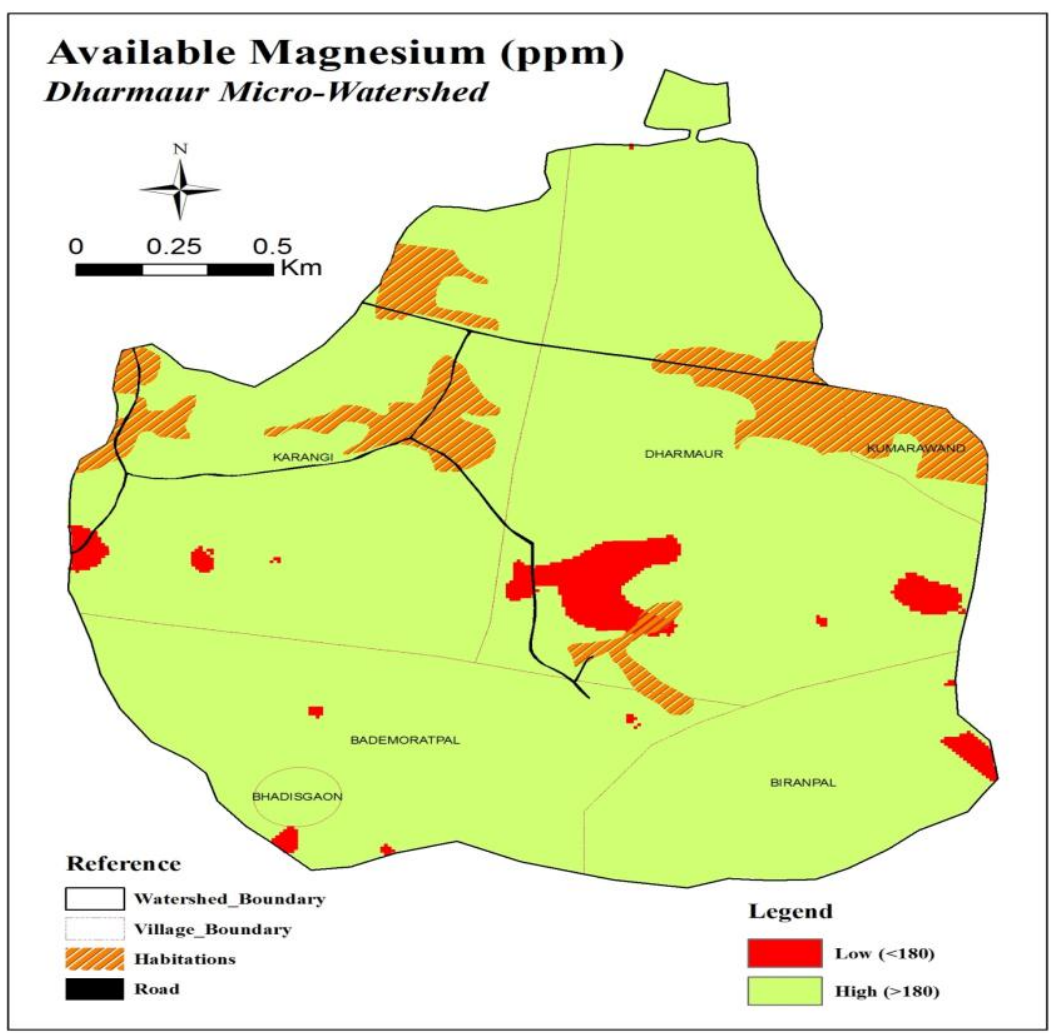

Fig.3 Status of available Mg in soils of Dharmaur micro-watershed 
Similar outcomes recorded by the elevated quantity of accessible $\mathrm{Ca}$ and $\mathrm{Mg}$ in district soils could be linked to the type and quantity of clay as well as the substitution of these fundamental cations on the exchange complex. Because these soils are mostly neutral and have low CEC, this could be due to the least leaching of bases and medium organic carbon values. Amara (2015) revealed similar results.

The distribution of available $\mathrm{Ca} \& \mathrm{Mg}$ in different farming situation in the map shows that $100 \%$ of soil samples of available Ca were low in Marhan, Tikra, Mal and Gabhar farming situation and $77.4 \%$ of soil samples of available $\mathrm{Mg}$ were high status and $22.5 \%$ were low in Marhan, Tikra, Mal and Gabhar farming situation. Distribution of rating available $\mathrm{Ca} \& \mathrm{Mg}$ status in the soils shown in Table 1.

\section{Descriptive statistics analysis}

The descriptive statistics of available calcium and magnesium are shown in Table 2 which suggested that they were all normally distributed. Kriging is a widely used method of geo-statistical interpolation that assumes no regional trend exists in the data. This method utilized the co-regionalization structure of soil properties and provided unbiased estimates and minimum variance (Ali and Malik, 2010). Skewness is the most common form of departure from normality. If a variable has positive skewness, the confidence limits on the variogram are wider than they would otherwise be, and consequently, the variances are less reliable. A logarithmic transformation is considered where the coefficient of skewness is greater than one (Webster and Oliver, 2001).

\section{References}

Agriculture Contingency Plan for District: Bastar by CRIDA Source: Agricultural Statistics 2009, Commissioner land records, Raipur, Govt. of Chhattisgarh.

Devdas, Deepika, 2016“soil fertility mapping and tracing out limiting nutrients as production constraints for Gariyaband district of Chhattisgarh" Ph.D thesis, I.G.K.V. Raipur, (Chhattisgarh).

Das, D.K. 2004. Introductory Soil Science. Kalyani Publishers, Ludhiana, 493.

Das, 2016 soil fertility mapping of Nayranpur through GPS and GIS

Webster R, Oliver MA (2001). Geostatistics for Environmental Scientists. Hoboken, N.J.: John Wiley and Sons Inc.

\section{How to cite this article:}

Shailja Iyer. S., G. P. Ayam and Thakur. D. S. 2020. Soil Fertility Status of Available Calcium and Magnesium in Soil through Soil Fertility Mapping using GPS and GIS Techniques of Dharmaur Micro-Watershed Jagdalpur Block, Bastar District of (C.G.) State, India. Int.J.Curr.Microbiol.App.Sci. 9(06): 248-253. doi: https://doi.org/10.20546/ijcmas.2020.906.031 